\section{PREVALENCE OF INJURIES IN BRAZILIAN RECREATIONAL STREET RUNNERS: META-ANALYSIS}

\author{
PREVALÊNCIA DE LESÕES EM CORREDORES DE RUA AMADORES BRASILEIROS:METANÁLISE
}

PREVALENCIA DE LESIONES EN CORREDORES DECALLEAFICIONADOS BRASILEÑOS: META-ANÁLISIS

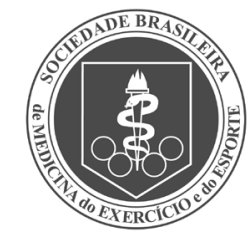

MetA-ANALYSIS

META-ANÁLISE META-ANÁLISIS
Wyngrid Porfirio Borel

(Physiotherapist)

José Elias Filho'

(Physiotherapist)

Juliano Bergamaschine Mata Diz

(Physiotherapist)

Poliana Fernandes Moreira

(Physiotherapist)

Priscila Monteiro Veras'

(Physiotherapist)

Leonardo Lacerda Catharino

(Physiotherapist)

Bárbara Palmeira Rossi

(Physiotherapist)

Diogo Carvalho Felício

(Physiotherapist)

1. Universidade Federal de Juiz de Fora, Post-Graduate Degree Program in Rehabilitation Sciences and Physical Functional Performance, Juiz de Fora, MG, Brazil.

\section{Correspondence}

Wyngrid Porfirio Borel. Master's Program in Rehabilitation Sciences UFJF, Faculdade de Fisioterapia. Av. Eugênio do Nascimento, $s / n$, Bairro Dom Bosco, Juiz de Fora, MG, Brazil. 36038-330 wyn_fisio@yahoo.com.br

\begin{abstract}
Street running is an accessible, low-cost form of exercise. However, the occurrence of musculoskeletal injuries may hinder regular practice. This study aimed at estimating the prevalence of injuries in Brazilian street runners and the associated factors. A meta-analysis of Brazilian studies was performed to investigate the prevalence and risk factors of injuries in male and female recreational street runners aged $\geq 18$ years. We excluded systematic review studies, research conducted on professional athletes or triathletes, and duplicate articles. The following databases were used: SciELO, LILACS, PubMed, Web of Science, and Google Scholar. Keywords such as "prevalence," injury,"'recreational street runners," and "Brazil" were used. Prevalence analysis was performed using the random effect model, and a funnel plot was used to assess publication bias. Then the Begg-Mazumdar and Egger tests were applied to quantify the graph results. The Prevalence Critical Appraisal Instrument was used to evaluate the methodological quality of the studies. Associated factors were analyzed with meta-regression analysis. Twenty-three studies with 3,786 runners were included in the review. The prevalence of injury was $36.5 \%$ (95\% confidence interval [CI] 30.8-42.5\%), and a running distance per week greater than $20 \mathrm{~km}$ was a predictive variable of injuries. A higher prevalence of injuries was observed in men than in women $(28.3 \%, 95 \%$ Cl 22.5-35.0\%), the knee was the most affected site of injury (32.9\%, 95\% Cl 26.7-39.6\%), and muscle injuries were the most frequent type of injury $(27.9 \%, 95 \% \mathrm{Cl} 18.2-40.1 \%)$. This is the first national meta-analysis conducted to investigate the prevalence of injuries in recreational street runners. Although the prevalence of injuries was moderate, caution is required in terms of the weekly duration of running. Male runners are more susceptible, and muscle and knee injuries are the most common. Level of evidence II, Systematic review ${ }^{b}$ of Level II Studies.
\end{abstract}

Keywords: Prevalence; Injury; Running.

\section{RESUMO}

A corrida de rua é uma forma de exercício acessivel e de baixo custo. No entanto, a ocorrência de lesões musculoesqueléticas pode dificultar a prática regular. O objetivo deste estudo foi estimar a prevalência de lesões em corredores de rua brasileiros e os fatores associados. Foi realizada uma metanálise de estudos brasileiros para investigara prevalência e os fatores de risco de lesão em corredores de rua amadores, de ambos os sexos, com idade $\geq 18$ anos. Foram excluídos estudos de revisão sistemática, pesquisas com atletas profissionais ou triatletas e os artigos duplicados. As buscas eletrônicas foram feitas nos seguintes bancos de dados: SciELO, LILACS, PubMed, Web of Science e Google Acadêmico. Foram usados descritores como "prevalência", "lesão", "corredores de rua amadores" e "Brasil". A análise de prevalência foi realizada com o modelo de efeito aleatório, e um gráfico de funil foi usado para avaliar o viés de publicação. Em seguida, os testes Begg-Mazumdar Egger foram aplicados para quantificar os resultados do gráfico. O Prevalence Critical Appraisal Instrument foi usado para avaliar a qualidade metodológica dos estudos. Os fatores associados foram analisados com análise de metarregressão. Vinte e três estudos, totalizando 3.786 corredores foram incluidos na revisão. A prevalência de lesões foi de 36,5\% (intervalo de confiança [IC] de 95\% 30,8-42,5\%), e a distância percorrida por semana superior a $20 \mathrm{~km}$ foi uma variável preditiva de lesões. Observou-se maior prevalência de lesões em homens do que em mulheres (28,3\%, IC de 95\% 22,5-35,0\%). O joelho foi o local mais acometido (32,9\%, (IC de $95 \% 26,7-39,6 \%)$ e as lesões musculares foram as mais frequentes (27,9\%, IC de 95\% 18,2-40,1\%). Esta é a primeira metanálise nacional a investigar a prevalência de lesões em corredores de rua amadores. Embora a prevalência de lesões tenha sido moderada, é preciso ter cautela em termos da duração semanal da corrida. Os corredores do sexo masculino são mais suscetíveis, e as lesões musculares e do joelho são as mais comuns. Nível de evidência ll, Revisão sistemática ${ }^{b}$ de Estudos de Nível II.

Descritores: Prevalência; Lesão; Corrida.

\section{RESUMEN}

La carrera de calle es una modalidad de accesible y de bajo costo. Sin embargo, la aparición de lesiones musculo esqueléticas puede dificultar la práctica regular. El objetivo de este estudio fue estimar la prevalencia de lesiones en corredores de calle brasileños y los factores asociados. Se realizó un meta-análisis de estudios brasileños que investigaron la prevalencia y los factores de riesgo de lesión en corredores de calle aficionados, de ambos sexos, con edad $\geq 18$ años. Se excluyeron estudios de revisión sistemática, investigaciones con atletas profesionales o triatletas y los artículos duplicados. Las búsquedas electrónicas se realizaron en las siguientes bases de datos: SciELO, LILACS, PubMed, Web of 
Science y Google Académico. Se utilizaron descriptores como "prevalencia", "lesión", "corredores de calle aficionados" y "Brasil". El análisis de prevalencia se realizó con el modelo de efecto aleatorio, y un gráfico de embudo se utilizó para evaluar el sesgo de publicación. A continuación, se aplicaron las pruebas Begg-Mazumdar y Egger para cuantificar los resultados del gráfico. El Prevalence Critical Appraisal Instrument se utilizó para evaluar la calidad metodológica de los estudios. Los factores asociados fueron analizados con análisis de meta-regresión. Se incluyeron 23 estudios en la revisión, totalizando 3.786 corredores, con prevalencia de lesiones del 36,5\% (intervalo de confianza [IC] del 95\% 30,8-42,5\%), y la distancia recorrida por semana superior a $20 \mathrm{Km}$ fue una variable predictiva de lesiones. Se observó mayor prevalencia de lesiones en hombres que en mujeres (28,3\%, IC del 95\% 22,5-35,0\%). La rodilla fue el local más afectado (32,9\%, IC del 95\% 26,7-39,6\%) y las lesiones musculares fueron las más frecuentes (27,9\%, IC del 95\% 18,240,1\%). Este es el primer meta-análisis nacional en investigar la prevalencia de lesiones en corredores aficionados. Aunque la prevalencia de lesiones ha sido moderada, se requiere precaución en cuanto a la duración semanal de la carrera. Los corredores del sexo masculino son más susceptibles, y las lesiones musculares y de la rodilla son las más comunes. Nivel de evidencia II, Revisión sistemática ${ }^{b}$ de Estudios de Nivel II.

Descriptores: Prevalencia; Lesión; Carrera.

\section{INTRODUCTION}

Street running is an accessible, low-cost, simple form of exercise, and it is a contemporary social phenomenon. ${ }^{1,2}$ A regular running practice provides several health benefits. However, when performed improperly or unguided, it might cause injury., ${ }^{3,4}$ Injuries in street runners lead to work absenteeism, increased demand for health services, and discontinuity in training or competitions. ${ }^{5}$

In a recent study, Smits et al ${ }^{6}$ evaluated absenteeism and health care after the occurrence of running-related injury over a period of six weeks. One hundred eighty-five subjects participated in the study. Work absenteeism was observed in $4 \%$ of individuals, and $51 \%$ sought a health professional. In another study, researchers investigated the economic burden of running-related injuries in Dutch athletes. One thousand six hundred ninety-six individuals participated in the study, and the incidence of injuries was observed in 272 cases. Health care injuries expenses were R\$207.30 in addition to $\mathrm{R} \$ 95.70$ for work absenteeism. ${ }^{7}$ In a similar study design that included 53 Dutch street runners, injuries were observed in 41 cases. Health care expenses for the treatment of these injuries and paid work absenteeism accounted for $\mathrm{R} \$ 630.70 .{ }^{8}$ In Brazil, we did not find data on this subject.

In a prospective cohort study of 200 Brazilian recreational street runners, Hespanhol Junior et al ${ }^{9}$ revealed that the incidence of injuries might increase from 31\% over three months to $51 \%$ over a year. This high injury rate culminates in the discontinuity of training or competitions, and aggravates the harm resulting from a sedentary lifestyle, which is a worldwide concern. ${ }^{10}$ Musculoskeletal injuries in street runners might also cause a psychosocial impact and reduce the level of motivation to continue sports activity. The occurrence of an injury might also cause anxiety, low self-esteem, excessive anger, obsession to return to sports with premature training resumption, worsening of the injury, and a feeling of helplessness while treating the injury. ${ }^{11}$

Determining the prevalence of injuries in street runners and the associated risk factors could contribute to reducing work absenteeism and the demand for health services, and encourage regular sports activity. In addition, the information may be used to define preventive strategies and improve rehabilitation programs. Systematically and critically compiled data on the prevalence of injuries in recreational street runners in Brazil do not exist.

Therefore, the objectives of this meta-analysis were to investigate the prevalence of injuries in Brazilian recreational street runners; to analyze the risk of bias in eligible studies; to investigate the relationship between training characteristics and the onset of injuries; to verify the gender influence on the prevalence of lesions; to identify the most affected anatomic sites and the most common type of lesions.

\section{METHODS}

We performed a systematic review and meta-analysis. The methodology followed the recommendation of the Joanna Briggs Institute Reviewers' Manual (The Systematic Review of Prevalence and Incidence Data) ${ }_{1}^{12}$ guidelines of the MOOSE group (Meta-analysis of Observational Studies in Epidemiology) $)^{13}$ and Cochrane Collaboration. ${ }^{14}$ Additionally, this systematic review was reported according to the PRISMA checklist (Preferred Reporting Items for Systematic Reviews and Meta-Analyses). ${ }^{15}$

\section{Eligibility criteria}

We included all studies conducted in Brazil that investigated the prevalence at the point, during or throughout the life of injuries in recreational street runners of both genders, aged $\geq 18$ years. A recreational street runner was defined as someone who practices this activity for pleasure and health benefits without remuneration. ${ }^{16}$ We included studies regardless of the severity of the symptoms of injury (i.e., acute, subacute, or chronic). Systematic review studies, studies performed with samples of professional athletes and triathletes, and duplicate articles in more than one database were excluded from this investigation. When the same sample was used to report the prevalence of injuries in more than one study, only the work presenting the largest sample size was included in this research. For questions about an article's eligibility, we contacted the authors.

Titles and abstracts were reviewed initially. The inclusion of full potential texts was evaluated by two independent reviewers (WPB and JEF), according to the eligibility criteria, and a third reviewer (DCF) resolved the differences.

\section{Search strategy}

Electronic searches were conducted from the oldest record until the date preceding the submission of the article. We used the following databases: SciELO, LILACS, PubMed, and Web of Science without language restriction. In addition, a second review of related literature was performed using Google Scholar and the reference lists of all eligible studies. The search strategy used the following English and Portuguese keywords:" prevalence,"'epidemiology,"'injury,"'street runners,","recreational runners," and "Brazil," which were Medical Subject Headings. These keywords were also combined with each other using Boolean operators and/or added to all descriptors. 


\section{Data extraction}

Two independent reviewers (WPB and JEF) extracted relevant data of the study subjects using a pre-defined data extraction form, and disagreements were solved by a third reviewer (DCF).

The following data were extracted: the type of study, definition of injury, number of participants, and prevalence of injury. For the prevalence of injury, the percentage and absolute number of events (injuries) were extracted.

\section{Statistical analysis}

The data were initially analyzed using descriptive statistics. Prevalence estimates and their respective confidence intervals (ICs) were obtained from the total sample size and the number of events (injuries) for each study included in the review. Prevalence estimates are expressed as percentages (proportion $\times 100$ ). ${ }^{12}$

The $l^{2}$ statistic was used to assess homogeneity between studies. In the meta-analysis, studies had low heterogeneity if $\mathrm{l}^{2}<50 \%$ or moderate to high heterogeneity if $\mathrm{I}^{2} \geq 50 \%$. Grouped effects were estimated using the random effect model. A funnel plot was used to determine publication bias. The Begg-Mazumdar and Egger tests were performed to verify the statistical significance of plot results in potential cases. ${ }^{14}$

After estimating the prevalence of injuries in recreational runners, two independent reviewers (WPB and JEF) evaluated the risk of bias for each study using a validated instrument that included 10 items, which assessed the risk of bias in prevalence studies. ${ }^{12}$ Each item was classified as "yes", "no," and "not clear" according to the information given in the article, and a maximum positive score of 10 points was permitted. A third reviewer (DCF) resolved potential disagreements.

Subsequently, meta-regression analyses were performed with the aim to investigate the relationship between training characteristics (frequency of running [weekly], running distance, and running experience [years]) and the onset of injuries, to verify the effect of sex on the prevalence of injuries, to evaluate the most affected anatomic sites (e.g., the hip, knee, and ankle), and to verify the most frequent types of injuries (muscular, inflammatory, bony, and ligament injuries).

The level of significance was $5 \%$ for all statistical tests. All statistical analyses were performed using the Comprehensive Meta-Analysis program, version 3.3.070 (Biostat Inc., Englewood, NJ, USA).

\section{RESULTS}

Four hundred forty-eight studies were investigated. Of these, 54 were eligible for full-text analysis, and 16 were excluded after evaluating the full-text article. Of the excluded articles, 13 were systematic reviews that used samples from professional runners and triathletes, and three other studies had duplicate samples. An additional 15 studies were excluded because they were found in duplicate databases. The flow chart of studies is shown in Figure 1.

\section{Description of the included studies}

Of the 23 included studies, 20 were performed using samples collected from both sexes. Among 3,786 participants, 2,605 were men. Twenty studies were cross-sectional, and three were prospective cohort investigations with prevalence data reported. The articles were published from 2009 to 2017. Table 1 shows that only 10 studies provided a definition of injury, and 13 studies did not present enough data to extract injury prevalence information in relation to participants'sex. The prevalence of injury ranged from $20 \%$ to $65.9 \%$ among the studies.

\section{Prevalence of injuries in Brazilian recreational street runners}

According to the meta-analysis of 23 studies, the prevalence of injuries was $36.5 \%$ (95\% Cl 30.8-42.5\%). The $\mathrm{I}^{2}$ value of 0.0 revealed a low heterogeneity among the studies (Figure 2).

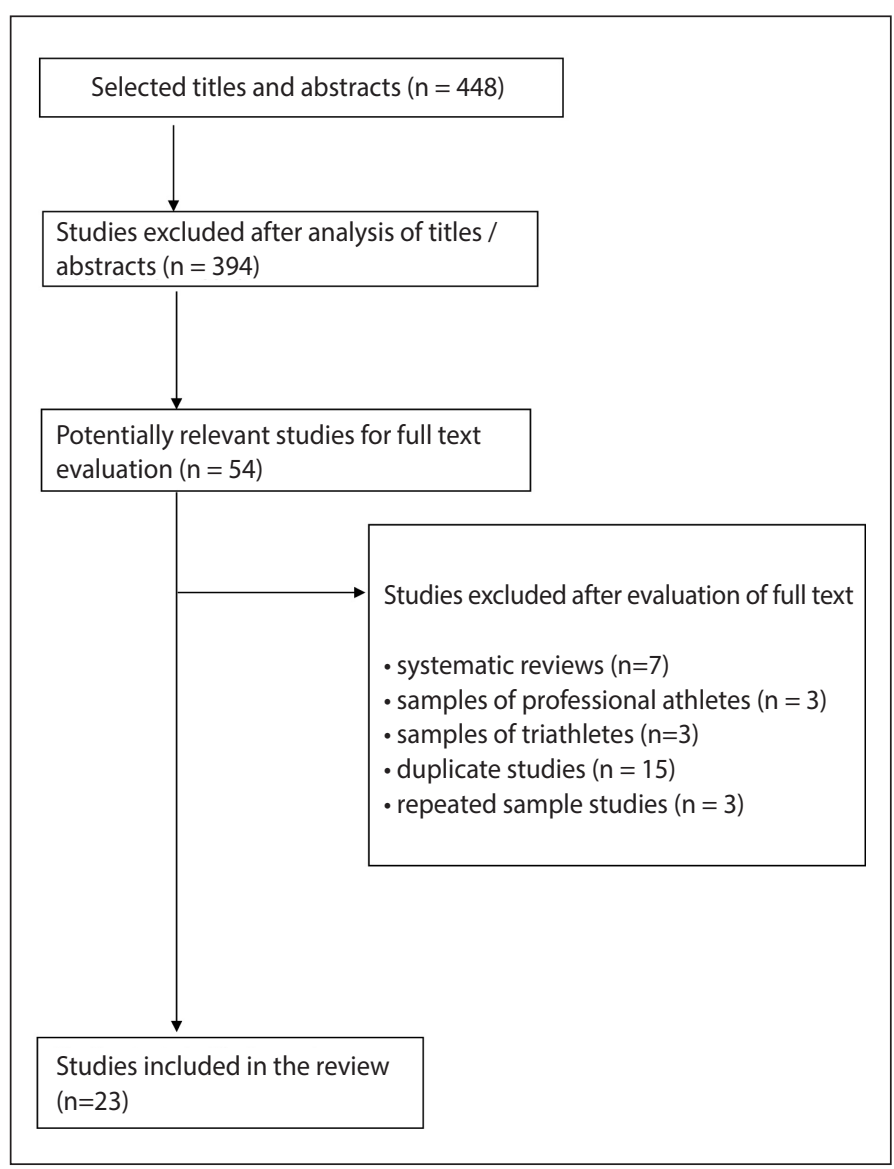

Figure 1. Flowchart of included studies.

\section{Risk assessment of bias}

Table 2 shows the risk assessment of bias of the included articles. The methodological quality varied from 5 to 9 points.

The funnel plot analysis showed no publication bias. Results of the Begg-Mazumdar $(p=0.270)$ and Egger tests $(t=1.21, d f=21, p=0.118)$ were not significant (Figure 3).

Analysis of the relationship between training characteristics and the occurrence of injury

The descriptive analysis showed that six studies showed a relationship between a running distance of $20 \mathrm{~km}$ or more per week and the occurrence of injuries, five studies showed a relationship between running experience of more than five years and the occurrence of injuries, and only four studies showed a relationship between a weekly training frequency greater than or equal to three days and the occurrence of injuries. Six studies did not investigate the effect of training variables and the occurrence of injuries. These research studies only analyzed training variables according to the entire sample, without distinction between injured and non-injured individuals, with the aim of describing the training profile of all runners.

\section{Prevalence of injury in recreational male and female street runners}

The prevalence of injury among male street runners was 28.3 (95\% Cl 22.5-35.0\%), whereas that among female street runners was 9.1\% (95\% Cl 5.3-15.2\%). The $\mathrm{I}^{2}$ value was 50 for men and that for women was 0.0 , indicating moderate and low heterogeneity, respectively.

Affected anatomical sites

The prevalence of knee injury was 32.9\% (95\% Cl 26.7-39.6\%), that of ankle injury was $17.7 \%(95 \% \mathrm{Cl} 11.2-26.9 \%)$, and that of hip injury was $13.3 \%$ (95\% Cl 6.9-24.1\%). The $\mathrm{I}^{2}$ value of 0.0 revealed low heterogeneity between those results. 
Table 1. Descriptive analysis of the characteristics of included studies $(n=23)$.

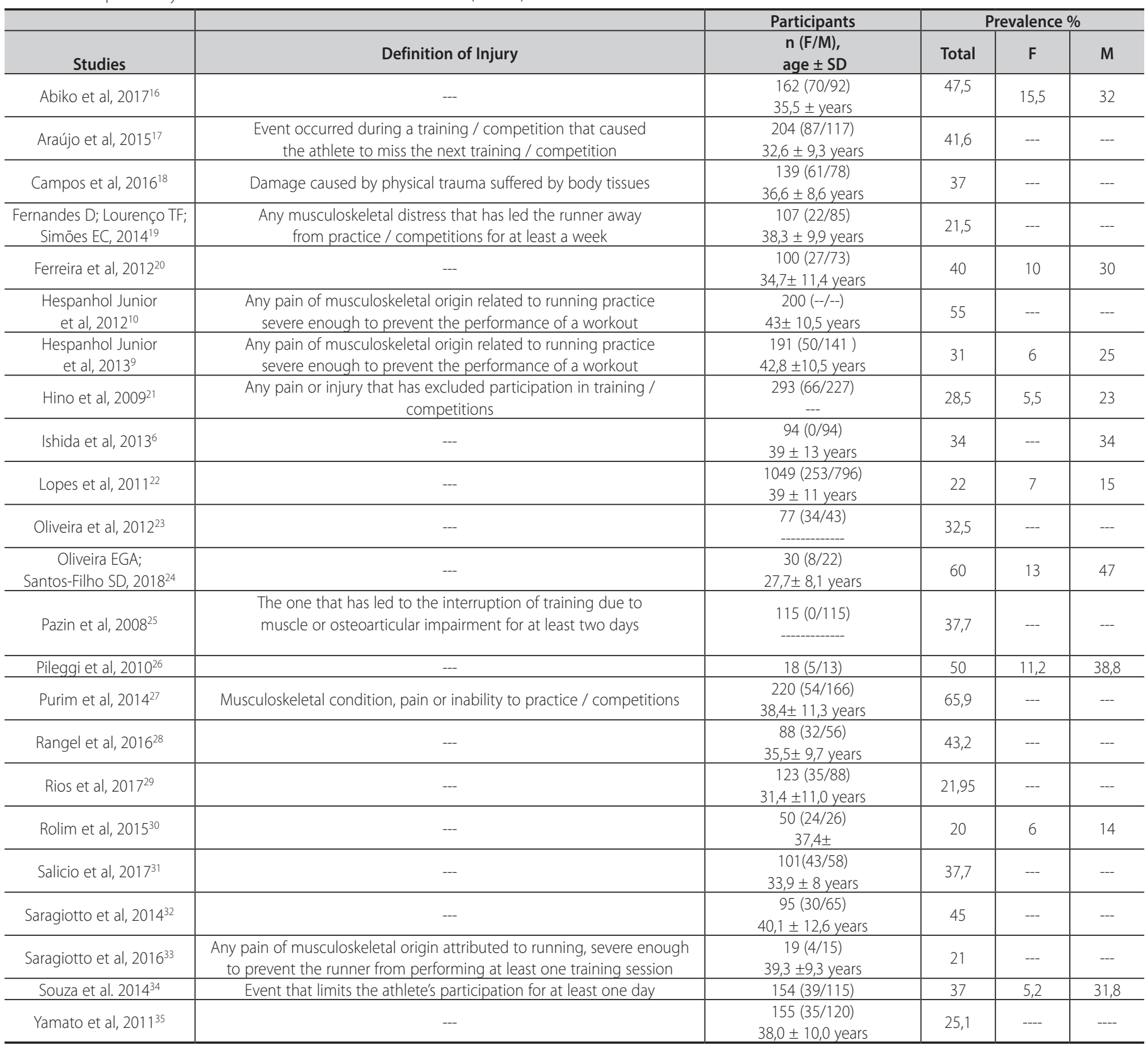

\section{Most common types of injuries}

The prevalence of muscle injuries, which included sprains, stretches and contractures, was $27.9 \%$ (95\% Cl 18.2-40.1\%). The prevalence of ligament injuries, such as sprains and dislocations, was $27.8 \%(95 \% \mathrm{Cl}$ 19.4-38.1\%). Plantar fasciitis, tendinitis, synovitis, bursitis, and medial stress syndrome of the tibia were grouped as inflammatory lesions, and their prevalence was $26.5 \%$ (95\% Cl 14.9-40.1\%). Bone injuries included fracture, chondromalacia patella and bone edema, and their prevalence was $5.6 \%$ (95\% Cl 1.8-16.3\%). The $\mathrm{I}^{2}$ value of 0.0 also revealed low heterogeneity for the results obtained in this subgroup.

\section{DISCUSSION}

This review is the first national meta-analysis that was performed to investigate the prevalence of injuries in 3,786 recreational street runners. The data herein provide moderate quality evidence that the prevalence of injuries in recreational street runners is $36.5 \%$. The distance of running per week is a predictive variable of injuries. Most injured individuals are men. The most affected anatomic site is the knee, and the most common injuries are muscular injuries.
This review revealed a prevalence of injuries in Brazilian recreational street runners of $36.5 \%$. A similar value was reported by Von Rosen et a ${ }^{37}$ in a study of 64 male and female participants, in whom the prevalence of injuries in street runners was $35.7 \%$. Our findings are also consistent with the study published by Kluitenberg et al, ${ }^{38}$ which included 1,696 male and female participants; $33.6 \%$ of the subjects reported injuries. The prevalence rate in our study is also in line with the ranges proposed in the systematic reviews published by Van Gent et al ${ }^{39}(19.4 \%$ to $79.3 \%)$ and Von der Worp et a $1{ }^{40}$ (20.6\% to $79.3 \%$ ). In soccer, the prevalence of injuries was $28.23 \%$ for teams of professional juvenile athletes, ${ }^{41}$ whereas the prevalence of musculoskeletal injuries in crossfit athletes with an average age of 32 years was $30.2 \%$. ${ }^{42}$ The findings confirm that running is associated with risks of musculoskeletal injuries; therefore, it is important to define preventive strategies to promote safe running practice.

We highlighted the divergence of national studies regarding the definition of injury. Most studies did not use a standard definition. Thus, several authors claimed that some differences in injury rates were certainly linked to different definitions used in each study, 22,39,43,44 corroborating our findings that the prevalence of injury ranged from $20 \%$ to $65.9 \%$. 
Table 2. Methodological quality of included studies $(n=23)$.

\begin{tabular}{|c|c|c|c|c|c|c|c|c|c|c|c|}
\hline Studies & 1 & 2 & 3 & 4 & 5 & 6 & 7 & 8 & 9 & 10 & Scores $(0-10)$ \\
\hline Abiko et al ${ }^{16}$ & Y & $U$ & $N$ & N & N & Y & N & Y & Y & Y & 5 \\
\hline Araújo et al ${ }^{17}$ & Y & Y & N & $\mathrm{N}$ & $N$ & Y & N & U & Y & $Y$ & 5 \\
\hline Campos et al ${ }^{18}$ & Y & $Y$ & $N$ & $N$ & $N$ & Y & $N$ & Y & Y & $U$ & 5 \\
\hline Fernandes et al ${ }^{19}$ & Y & Y & $N$ & N & N & U & N & Y & Y & Y & 5 \\
\hline Ferreira et $a^{20}$ & Y & Y & $\mathrm{N}$ & Y & $Y$ & Y & N & Y & Y & $Y$ & 8 \\
\hline Hespanhol Junior et al ${ }^{10}$ & Y & Y & $\mathrm{N}$ & $\mathrm{N}$ & $N$ & Y & $\mathrm{N}$ & Y & $Y$ & $Y$ & 6 \\
\hline Hespanhol Junior et al ${ }^{9}$ & Y & Y & $\mathrm{N}$ & $\mathrm{N}$ & $Y$ & Y & $\mathrm{N}$ & Y & Y & Y & 7 \\
\hline Hino et $\mathrm{al}^{21}$ & Y & Y & $\mathrm{N}$ & $\mathrm{N}$ & $N$ & U & Y & U & $Y$ & $Y$ & 6 \\
\hline $\mid$ shida et $\left.a\right|^{6}$ & Y & $Y$ & $\mathrm{~N}$ & Y & $Y$ & Y & $\mathrm{N}$ & Y & Y & $Y$ & 8 \\
\hline Lopes et $\mathrm{al}^{22}$ & Y & Y & Y & Y & $Y$ & Y & $\mathrm{N}$ & Y & $Y$ & $Y$ & 9 \\
\hline Oliveira et $\left.\right|^{23}$ & Y & Y & N & U & U & Y & N & Y & U & $Y$ & 5 \\
\hline Oliveira;Santos Filho ${ }^{24}$ & Y & Y & N & $\mathrm{N}$ & $N$ & Y & N & Y & U & $Y$ & 5 \\
\hline Pazin et $a^{25}$ & Y & Y & Y & N & $N$ & Y & N & Y & $Y$ & $\mathrm{~N}$ & 6 \\
\hline Pileggi et al ${ }^{26}$ & $Y$ & $Y$ & N & $Y$ & $Y$ & Y & Y & $Y$ & $Y$ & $Y$ & 9 \\
\hline Purim et $\mathrm{al}^{27}$ & $Y$ & $Y$ & $\mathrm{~N}$ & $\mathrm{~N}$ & $N$ & Y & $\mathrm{N}$ & Y & $Y$ & $Y$ & 6 \\
\hline Rangel et al ${ }^{28}$ & $Y$ & Y & $\mathrm{N}$ & N & $N$ & Y & N & Y & $Y$ & $Y$ & 6 \\
\hline Rios et al ${ }^{29}$ & $Y$ & Y & N & $\mathrm{N}$ & $N$ & Y & $\mathrm{N}$ & U & $Y$ & $Y$ & 5 \\
\hline Rolim et $\mathrm{al}^{30}$ & $Y$ & Y & $\mathrm{N}$ & U & $N$ & Y & N & Y & U & $Y$ & 5 \\
\hline Salicio et $\mathrm{al}^{31}$ & $Y$ & Y & N & U & $N$ & Y & $\mathrm{N}$ & U & $Y$ & $Y$ & 5 \\
\hline Saragiotto et $\mathrm{al}^{32}$ & $Y$ & $Y$ & $\mathrm{~N}$ & Y & $Y$ & Y & $\mathrm{N}$ & Y & $Y$ & $Y$ & 8 \\
\hline Saragiotto et al ${ }^{33}$ & $Y$ & $Y$ & $\mathrm{~N}$ & Y & $N$ & Y & Y & Y & $Y$ & $Y$ & 8 \\
\hline Souza et $\mathrm{al}^{34}$ & Y & $Y$ & N & Y & U & Y & N & N & N & $Y$ & 5 \\
\hline Yamato et $a^{35}$ & $Y$ & $Y$ & $N$ & $N$ & U & $Y$ & $\mathrm{~N}$ & $Y$ & $Y$ & $Y$ & 6 \\
\hline
\end{tabular}

1. Was the sample representative of the target population? 2 Were study participants recruited in an appropriate way? 3. Was the sample size adequate? 4 . Were the study subjects and setting described in detail? 5 . Is the data

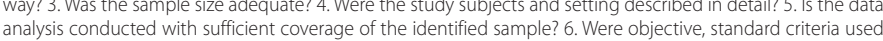
for measurement of the condition? 7. Was the condition measured reliably? 8. Was there appropriate statistical analysis? 9 . Are all important confounding factors/ subgroups/differences identified and accounted for? 10. Were subpopulations identified using objective criteria? $Y=$ yes; $N=$ no; $U=$ unclear
The lack of a standard definition hinders the comparison of studies. Hence, a standard definition of running-related injury, specifically for street runners, may contribute to reducing the large variations observed in reported injury rates.

Regarding training characteristics, the running distance was the main variable related to the onset of injuries. Van Poppel et a ${ }^{45}$ and Van der Worp et $\mathrm{a}^{40}$ also found a positive correlation between injuries and runners running distances greater than 20 kilometers per week. However, studies pointed out that other training characteristics may also predispose individuals to develop injuries, such as previous injuries and running speed. 9,39,46 Therefore, it is necessary to conduct longitudinal studies to investigate these variables.

In relation to sex, the present study's results showed that most runners are men and that the prevalence of injuries is also higher in this sex. A higher percentage of men was also observed in previous studies, 9,37,46 which may be related to social structure since women have a double working day. It may also be associated with the characteristics of running itself, as it is a sport with greater impact and low socialization. ${ }^{47}$ It has been suggested that inadequate flexibility, muscle imbalances, and deficits in neuromuscular coordination may cause inadequate movement patterns, which increase the risk of injuries in men. ${ }^{48}$ Additionally, the risk profile in men could be also related to the higher running speed and greater distance of running per week. ${ }^{40,49}$

Concerning the anatomical region, we observed that the knee is the most affected site of injury, with a prevalence of 33.5\%. A similar value was reported by Van Poppel et al ${ }^{45}$ (31.1\%) for knee injuries in 713 subjects. The literature indicates that the high rate of knee injuries in recreational runners is related to mechanical overload caused by the impact of running. ${ }^{34,49,50}$ The magnitude of impact forces acting on the lower limbs during running can range from one and a half to three times one's body weight. ${ }^{51}$ However, there is evidence that running practice is a protective factor for knee and hip osteoarthritis in recreational street

\section{Study name}

Abiko et al, 2017

Araújo et al, 2015

Campos et al, 2016

Fernandes et al, 2014

Ferreira et al, 2012

Hespanhol Junior et al, 2012

Hespanhol Junior et al, 2013

Hino et al, 2009

Ishida et al, 2013

Lopes et al, 2011

Oliveira et al, 2012

Oliveira; Santos-Filho 2018

Pazin et al, 2012

Pieggi et al, 2010

Purim et al, 2014

Rangel et al, 2016

Rios et al, 2017

Rolim et al, 2015

Salicio et al, 2017

Saragiotto et al, 2014

Saragiotto et al, 2016

Souza et al, 2014

Yamato et al, 2011
Statistics for each study

Event

rate

0.457

0.416

0.370

0.215

0.400

0.550

0.310

0.285

0.340

0.220

0.325

0.600

0.377

0.500

0.659

0.432

0.219

0.200

0.377

0.450

0.210

0.370

0.251

0.365

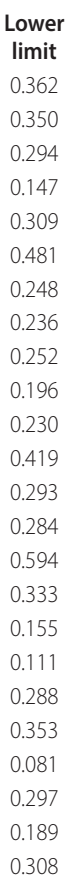

Upper limit Z-Value

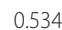

0.485

0.453

0.303

0.499

0.618

0.379

0.339

0.441

0.246

0.437

0.757

0.469

0.716

0.719

0.537

0.301

0.333

0.475

0.551

0.445

0.449

0.325

0.425

\section{$-1.093$}

$-2.388$

$-3.029$

$-5.503$

$-1.966$

1.412

$-5.114$

$-7.131$

$-3.046$

$-16.981$

$-3.004$

1.088

$-2.611$

0.000

4.632

$-1.272$

$-5.832$

$-3.921$

$-2.446$

$-0.973$

$-2.352$

$-3.189$

$-5.902$

$-4.322$
Event rate and $95 \% \mathrm{Cl}$

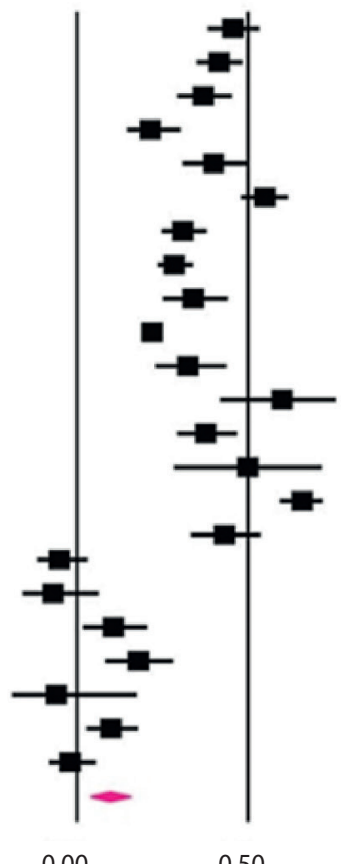

1.00

Prevalence

Figure 2. Forest plot of the prevalence meta-analysis of lesions and their respective confidence intervals 


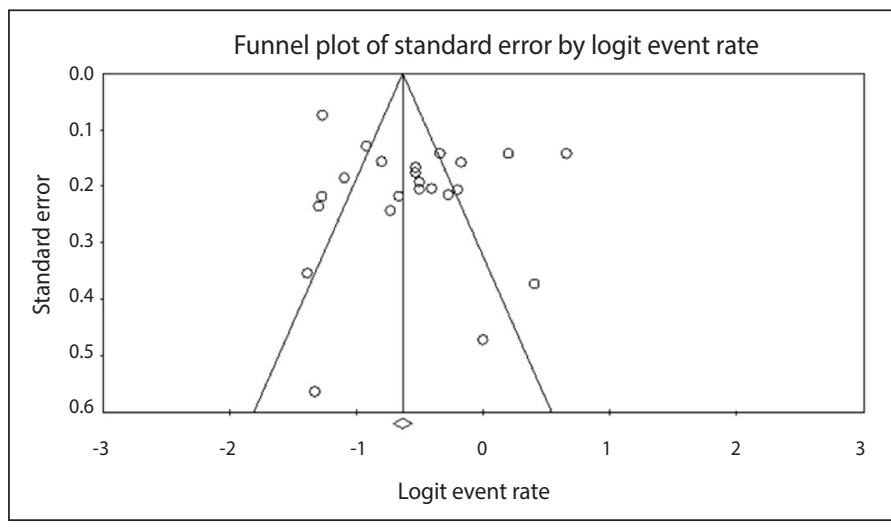

Figure 3. Funnel graph of the standard error by event rate $(n=23)$.

runners compared to sedentary individuals and professional runners. This is because the weekly running distance of recreational runners is generally less than 20-40 km, and their running experience is about 15 years. ${ }^{52,53}$ We infer that knee pain has a multifactorial origin, such as load and training volume, body mass index, concomitant practice of another type of exercise, biomechanical alterations, soil type and footwear, and other factors that must be considered to prevent knee pain.

Regarding the type of injuries, muscle consequences showed the highest prevalence rate, $27.9 \%$, followed by ligament injuries, $27.8 \%$, inflammatory injuries, 26.6\%, and bony injuries, 5.6\%. In the study published by Hespanhol Junior et al,7 $29.5 \%$ of subjects had inflammatory injuries and $30.3 \%$ had muscle injuries. Nielsen et a ${ }^{54}$ reported that inflammatory injuries accounted for 38\%, muscle injuries comprised $20 \%$, and bone lesions accounted for $6 \%$. Baumann et al ${ }^{55}$ suggested that muscle injuries in runners result from eccentric muscle actions, the generation of more muscle torque, and activation of fewer motor units for a particular load. This causes a high degree of mechanical stress on activated muscle fibers, failure in the excitation contraction coupling, and damage of muscle structures. Poorly supplied tissues, such as ligaments, are also particularly at risk, since they adapt slowly to an increase in mechanical load. ${ }^{40}$

The limitations of the study include the moderate quality of evidence, use of self-administered questionnaires that can lead to memory bias, and lack of standard collected information, thus compromising a more detailed interpretation of the data. Longitudinal studies are needed to comprehensively investigate predictive factors of injury.

\section{CONCLUSIONS}

The prevalence of injuries in Brazilian recreational street runners was $36.5 \%$ among 3,786 runners. The running distance per week was greater than $20 \mathrm{~km}$ and predictive of the occurrence of injury. Additionally, most injured individuals were men. The most affected anatomic site of injury was the knee, and the most common types of injury were muscular ones. The prevalence of injuries was moderate, although caution is required regarding the duration of running per week.

All authors declare no potential conflict of interest related to this article

AUTHORS' CONTRIBUTIONS: Each author made significant individual contributions to this manuscript. WPB (0000-0002-1182-9856)* and DCF $(0000-0001-5138-1884)^{*}$ were the main contributors in the drafting of the manuscript. WPB (0000-0002-1182-9856)*, JEF (0000-0002-4251-0290)*, PFM (0000- 0002-9881- 4576)*, PMV (0000-0002- 0146- 3926)*, LLC $(0000-0002-2695-967 X)^{*}$ and BPR (0000-0003-4344-3082)* gathered clinical data and conducted the literature search. WPB (0000-0002-1182-9856)*, JEF (0000-0002-4251-0290)* and JBMD (0000-0002-2849-2081)* evaluated the statistical analysis data. DCF (0000-0001-5138-1884)*, JBMD (0000-0002-2849-2081)* and WPB (0000-0002-1182-9856)* revised the manuscript and contributed to the intellectual concept of the study. ${ }^{*}$ ORCID (Open Researcher and Contributor ID).

\section{REFERENCES}

1. Nielsen RO, Ronnow L, Rasmussen S, Lind M. A prospective study on time to recovery in 254 injured novice runners. PLoS One. 2014;9(6):1-6.

2. Kluitenberg B, Van Middelkoop M, Diercks RL, Hartgens F, Verhagen E, Smits DW, et al. The NLstartrun study: health effects of a running promotion program in novice runners, design of a prospective cohort study. BMC Public Health. 2013;13:685-92.

3. Smits DW, Huisstede B, Verhagen E, van der Worp H, Kluitenberg B, van Middelkoop M, et al. Short-Term Absenteeis mand Health Care Utilization Due to Lower Extremity Injuries Among Novice Runners: A Prospective Cohort Study. Clin J Sport Med. 2016;26(6);502-9

4. Hespanhol Junior LC, van Mechelen W, Postuma E, Verhagen E. Health and economic burden of running-related injuries in runners training for an event: A prospective cohort study. Scand J Med Sci Sports. 2016;26(9):1091-9.

5. Hespanhol Junior LC, Van Mechelen W, Verhagen E. Health and Economic Burden of Running-Related Injuries in Dutch Trailrunners: A Prospective Cohort Study. Sports Med. 2017;47(2):367-77.

6. Ishida JC, Turi BC, Pereira-Da-Silva M, Amaral SL. Presença de fatores de risco de doenças cardiovasculares e de lesões em praticantes de corrida de rua. Rev Bras Educ Fís Esporte. 2013;27(1):55-65.

7. Weinberg RS, Gould D. Fundamentos da Psicologia do Esporte e do Exercícios. 2nd ed. São Paulo: Artmed Editora; 2001.

8. Torcate EF, Pawlack AR, Oliveira AG, Ribas MR. Perfil Antropométrico E Dietético De Corredores De Rua Da Cidade De Curitiba. RBPFEX. 2016;10(61):670-8.

9. Hespanhol Junior LC, Costa LOP, Lopes AD. Previous injuries and some training characteristics predict running-related injuries in recreational runners: a prospective cohort study. Braz J Phys Ther. 2013;59(4):263-9.

10. Hespanhol Junior LC, Costa LOP, Carvalho ACA, Lopes AD. Perfil das características do treinamento e associação com lesões musculoesqueléticas prévias em corredores recreacionais: um estudo transversal. Braz JPhys Ther. 2012;16(1):46-53.

11. Stroup DF, Berlin JA, Morton SC, Olkin I, Williamson GD, Rennie D, et al. Meta-analysis of observational studies in epidemiology: a proposal for reporting. Meta-analysis Of Observational Studies in Epidemiology (MOOSE). JAMA. 2000;283(15):2008-12.

12. Munn Z, Moola S, Riitano D, Lisy. K. The development of acritical appraisal tool for use in systematic reviews addressing questions of prevalence. J Mark Access Health Policy. 2014;3(3):123-8.

13. Higgins PT, Green S, editors. Cochrane Handbook for Systematic Reviews of Interventions. 2011. [acesso em 06 de Novembro de 2016]. Disponível em: http://cochrane-handbook.org

14. Moher D, Liberati A, Tetzlaff J, Altman DG. The PRISMA Group (2009). Preferred Reporting Items for Systematic Reviews and Meta-Analyses: The PRISMA Statement. PLoSMed. 2009;6(6).
15. Running USA. National Runner Survey Transinf. [Internet]. 2013. [acesso em 2017 Jun 3] Disponível em: <http://www.runningusa.com/>

16. Abiko RH, Tamura SH, Borges PH, Bertolini SMMG. Prevalência de lesões musculoesqueléticas e fatores associados em corredores de rua. Ciência\&Saúde. 2017;10(2):109-13.

17. Araújo MK, Baeza RM, Zalada SRB, Alves PBRA, Mattos CA. Lesões em Praticantes Amadores de Corrida. Rev Bras Ortop. 2015;50(5):537-40.

18. Campos AC, Prata MS, Aguiar SS, Castro HO, Leite RD, Pires FO. Prevalência de Lesões em Corredores de Rua Amadores. RBCS. 2016;3(1)40-5.

19. Fernandes $D$, Lourenço TF, Simões EL. Fatores de risco para lesões em corredores de rua amadores do estado de São Paulo. RBPFEX. 2014;8(49):656-63.

20. Ferreira AC, Dias JMC, Fernandes RM, Sabino GS, Anjos MTS, Felício DC. Prevalência e fatores associados a lesões em corredores amadores de rua do município de Belo Horizonte, MG. Rev Bras Ciênc Esporte. 2012;18(4):252-5.

21. Hino AAF, Reis RS, Rodriguez-Anez CR, Fermino RC. Prevalência de lesões em corredores de rua e fatores associados. Rev Bras Med Esporte. 2009;15(1):36-9

22. Lopes AD, Costa LO, Saragiotto BT, Yamato TP, Adami F, Verhagen E. Musculoskeletal pain is prevalent among recreational runners who are about to compete: an observational study of 1049 runners. Physio ther. 2011;57(3):179-82.

23. 23. Oliveira DG, Espírito-Santo G, Souza IS, Floret M. Prevalência de lesões e tipo de treinamento de atletas amadores de corrida de rua. Corpus et Scientia. 2012;8(1):51-9.

24. Oliveira EG, Santos-Filho SD. Prevalência de lesões em corredores de rua amadores que percorrem até dez quilômetros. RSD. 2018;7(5):1-7.

25. Pazin J, Duarte MFS, Poeta LSG, Almeida M. Corredores de rua: características demográficas, treinamento e prevalência de lesões. Rev bras cineantropom desempenho hum. 2008;10(3):277-82.

26. Pileggi P, Gualano B, Souza M, Caparbo VF, Pereira RMR, Pinto ALS, et al. Incidência e fatores de risco de lesões osteomioarticulares em corredores: um estudo de coorte prospectivo. Rev Bras Educ Fís Esporte. 2010;24(4):453-62.

27. Purim KSM, KappTitski AC, Bento PCB, Leite N. Lesões Desportivas e Cutâneas em Adeptos de Corrida de Rua. Rev Bras Med Esporte. 2014;20(4):299-303.

28. Rangel GMM, Farias JM. Incidência de lesões em praticantes de corrida de rua do município de Criciúma, Brasil. Rev Bras Med Esporte. 2016;22(6):496-00.

29. Rios ET, Rodrigues FC, Rocha LF, Salemi VMS, Miranda DP. Influência do volume semanal e do treinamento resistido sobre a incidência de lesão em corredores de rua. RBPFEX. 2017;11(64):104-9.

30. Rolim JDC, Souza J, Bastos JS, Yamada E. Perfil dos Corredores de Rua de Uruguaiana. Anais do Salão 
Internacional de Ensino, Pesquisa e Extensão, 2015. [acesso em 24 de Abril de 2017] Disponível em <http://seer.unipampa.edu.br/index.php/siepe/issue/view/103>

31. Salicio VMM, Shimoya-Bittencourt W, Santos AL, Costa DR, Salício MA. Prevalência de lesões em corredores de rua em Cuiabá-MT. J Health Sci. 2017;19(2):78-82.

32. Saragiotto BT, Yamato TP, Hespanhol Junior LC, Rainbow MJ, Davis IS, Lopes AD. What are the main risk factors for running-related injuries? Sports Med. 2014;44(8):1153-63.

33. Saragiotto BT, Yamato TP, Cosialls AMH, Lopes AD. Desequilíbrio muscular dos flexores e extensores do joelho associado ao surgimento de lesão musculoesquelética relacionada à corrida: um estudo de coorte prospectivo. Rev Bras Ciênc Esporte. 2016;38(1):64-8.

34. Souza CAB, Santos C, Aquino FAO, Barbosa MLCB, Alvarez RBP, Turienzo TT, et al. Características do treinamento e associação de lesões em corredores dos 10 KM Tribuna |FM-Unilus. Revista UNILUS Ensino e Pesquisa. 2014;11(23):96-02.

35. Yamato TP, Saragiotto BT, Lopes AD. Prevalência de dor musculoesquelética em corredores de rua no momento em que precede o início da corrida. Rev Bras Ciênc Esporte. 2011;33(2):475-82.

36. Von Rosen P, Heijne AILM, Frohm A. Injuries and Associated Risk Factors Among Adolescent Elite Orienteerers: A 26-Week Prospective Registration Study. J Athl Train. 2016;51(4):321-8.

37. Kluitenberg B, van Middelkoop M, Smits DW, Verhagen E, Hartgens F, Diercks R, et al. The NLstart2run study: Incidence and risk factors of running-related injuries in novice runners. Scand J Med Sci Sports. 2015;25(5):515-23.

38. Van gent BR, Siem D, van Middelkoop M, van Os AG, Bierma-Zeinstra SM, Koes BW. Incidence and determinants of lower extremity running injuries in long distance runners: a systematic review. $\mathrm{Br}$ J Sports Med. 2007:41 (8):469-80,

39. Van der worp MP, Ten Haaf DS, Van Cingel R, De Wijer A, Nijhuis-van der Sanden MW, Staal JB. Injuries in Runners; A Systematic Review on Risk Factors and Sex Differences. PLoS One. 2015;10(2):1-18

40. Sena DA, Ferreira FM, Melo RHG, Taciro C, Carregaro RL, Oliveira Júnior SA. Análise da flexibilidade segmentar e prevalência de lesões no futebol segundo faixa etária. Fisioter Pesq. 2013;20(4):343-8.

41. Lopes P, Bezerra FHG, Filho AN, Brasileiro I, Neto PP, Júnior FS. Lesões osteomioarticulares entre os praticantes de crossfit. Motricidade. 2018;14(1):266-70.
42. Lopes AD, Hespanhol Júnior LC, Yeung SS, Costa LO. What are the main running-related musculoskeletal injuries? A Systematic Review. Sports Medicine. 2012;42(10):891-05.

43. Yamato TP, Saragiotto BT, Hespanhol Junior LC, Yeung SS, Lopes AD. Descriptors used to define running-related musculoskeletal injury: a systematic review. JOSPT. 2015;45(5):366-74.

44. Van Poppel D, Scholten-Peeters GG, van Middelkoop M, Verhagen AP. Prevalence, incidence and course of lower extremity injuries in runners during a 12-month follow-up period. Scand J Med Sci Sports. 2014;24(6):943-9.

45. Hespanhol Junior LC, de Carvalho AC, Costa LO, Lopes AD. Lower limb alignment characteristics are not associated with running injuries in runners: Prospective cohort study. Eur J Sport Sci. 2016;16(8):1137-44.

46. Silva SP, Pereira GS, Costa RS. Fatores sociodemográficos e atividade física de lazer entre homens e mulheres de Duque de Caxias/RJ. Ciênc Saúde Coletiva. 2011;16(11):4493-501.

47. Hotta T, Nishiguchi S, Fukutani N, Tashiro Y, Adachi D, Morino S, et al. Functional Movement Screen For Predicting Running Injuries In 18- To 24-Year-Old Competitive Male Runners. J Strength Cond Res. 2015;29(10):2808-15.

48. Buist I, Bredeweg SW, Bessem B, van Mechelen W, Lemmink KA, Diercks RL. Incidence and risk factors of running-related injuries during preparation for a 4-mile recreational running event. Br J Sports Med. 2010;44(8):598-604

49. Fredericson M, Misra AK. Epidemiology and an etiology of marathon running injuries. Sports Med. 2007;37(4):437-9

50. Lieberman DE, Venkadesan M, Werbel WA, Daoud Al, D'Andrea S, Davis IS, et al. Foot strike patterns and collision forces in habitually barefoot versus shod runners. Nature. 2010;463(7280):531-5.

51. Timmins KA, Leech RD, Batt ME, Edwards KL. Running and Knee Osteoarthritis: A Systematic Review and Meta analysis. Am J Sports Med. 2017;45(6):1447-57.

52. Alentorn-Geli E, Samuelsson K, Musahl V, Green CL, Bhandari M, Karlsson J. The association of recreational and competitive running with hip and knee osteoarthritis: a systematic review and meta-analysis. JOSPT. 2017;47(6):373-90.

53. Baumann CW, Green MS, Doyle JA, Rupp JC, Ingalls CP, Corona BT. Muscle Injury After Low-Intensity Downhill Running Reduces Running Economy. J Strength Cond Res. 2014;28(5):1212-8. 